Article

\title{
Life Cycle Assessment and Water Footprint of Hydrogen Production Methods: From Conventional to Emerging Technologies
}

\author{
Andi Mehmeti ${ }^{1} *$ (D), Athanasios Angelis-Dimakis ${ }^{2}$ (D), George Arampatzis ${ }^{3}$ (D), \\ Stephen J. McPhail ${ }^{4}$ and Sergio Ulgiati ${ }^{5}$ \\ 1 Department of Science and Technology, Parthenope University of Naples, 80143 Naples, Italy \\ 2 School of Applied Sciences, University of Huddersfield, Huddersfield HD1 3DH, UK; \\ a.angelisdimakis@hud.ac.uk \\ 3 School of Production Engineering and Management, Technical University of Crete, 73100 Chania, Greece; \\ geo.arampatzis@gmail.com \\ 4 DTE-PCU-SPCT, ENEA C.R. Casaccia, Via Anguillarese 301, 00123 Rome, Italy; stephen.mcphail@enea.it \\ 5 Department of Science and Technology, Parthenope University of Naples, 80134 Naples, Italy; \\ sergio.ulgiati@uniparthenope.it \\ * Correspondence: andi.mehmeti@uniparthenope.it; Tel.: +39-327-556-3659
}

Received: 26 December 2017; Accepted: 2 February 2018; Published: 6 February 2018

\begin{abstract}
A common sustainability issue, arising in production systems, is the efficient use of resources for providing goods or services. With the increased interest in a hydrogen $\left(\mathrm{H}_{2}\right)$ economy, the life-cycle environmental performance of $\mathrm{H}_{2}$ production has special significance for assisting in identifying opportunities to improve environmental performance and to guide challenging decisions and select between technology paths. Life cycle impact assessment methods are rapidly evolving to analyze multiple environmental impacts of the production of products or processes. This study marks the first step in developing process-based streamlined life cycle analysis (LCA) of several $\mathrm{H}_{2}$ production pathways combining life cycle impacts at the midpoint (17 problem-oriented) and endpoint (3 damage-oriented) levels using the state-of-the-art impact assessment method ReCiPe 2016. Steam reforming of natural gas, coal gasification, water electrolysis via proton exchange membrane fuel cell (PEM), solid oxide electrolyzer cell (SOEC), biomass gasification and reforming, and dark fermentation of lignocellulosic biomass were analyzed. An innovative aspect is developed in this study is an analysis of water consumption associated with $\mathrm{H}_{2}$ production pathways by life-cycle stage to provide a better understanding of the life cycle water-related impacts on human health and natural environment. For water-related scope, Water scarcity footprint (WSF) quantified using Available WAter REmaining (AWARE) method was applied as a stand-alone indicator. The paper discusses the strengths and weaknesses of each production pathway, identify the drivers of environmental impact, quantify midpoint environmental impact and its influence on the endpoint environmental performance. The findings of this study could serve as a useful theoretical reference and practical basis to decision-makers of potential environmental impacts of $\mathrm{H}_{2}$ production systems.
\end{abstract}

Keywords: hydrogen production; LCA; sustainability; water footprint; indicators

\section{Introduction}

Due to a visionary low-carbon economy, hydrogen $\left(\mathrm{H}_{2}\right)$ has received a great deal of attention as an energy carrier from both scientists and policymakers over the last decade [1]. However, the use of hydrogen as a fuel input requires a reliable production technology and an efficient distribution network. Hydrogen can be produced from diverse feedstocks (renewable energy, nuclear energy, and 
fossil fuels) using a variety of chemical, electrochemical and biological process technologies. In the long term, a hydrogen-based economy could contribute towards reducing carbon dioxide $\left(\mathrm{CO}_{2}\right)$ emissions and local environmental pollution, securing energy independence and achieving a sustainable energy supply. Within this context, the life cycle thinking is increasingly seen as a key concept for analyzing systematically processes and production systems, seeking to incorporate externalities that have major implications for long-term sustainability [2].

One of the tools that can facilitate industrial decision making towards sustainable resource management is Life Cycle Assessment (LCA). LCA is a standardized methodology that allows the compilation and evaluation of inputs, outputs and potential environmental impacts of a product system throughout its life cycle [3]. LCA application on $\mathrm{H}_{2}$ production has increased rapidly to guide challenging decisions and select between technology paths [4]. Spath and Mann [5] assessed the environmental performance of hydrogen production via natural gas steam reforming, including air and waste emissions, energy requirements and resource consumption. Utgikar and Thiesen [6] used global warming potential and acidification impact categories to characterize high-temperature electrolysis for hydrogen production via nuclear energy. Koroneos et al. [7] studied the environmental feasibility of hydrogen produced by biomass gasification. Cetinkaya et al. [8] used LCA for five methods of hydrogen production using energy equivalent and global warming potential (GWP) as criteria for evaluation. Acar and Dincer [9] comparatively assessed them for environmental impacts (global warming and acidification potential), cost, and energy efficiency. Up to date, the LCA of most studies on $\mathrm{H}_{2}$ production technologies discusses mainly the GWP impact category and the Centre for Environmental Studies (CML) version is found to be the most applied life cycle impact assessment methodology $[10,11]$. A review of all LCA studies of hydrogen energy systems is provided by Valente et al. [11] indicating the need for a harmonized framework to provide consistent and comparable life cycle impacts that help identify the most favorable systems. Thus, a comprehensive evaluation of the different systems for hydrogen production should be carried out in order to check their suitability according to sustainability criteria.

One of the most recent outcomes of the life cycle assessment community is the LCA-ReCiPe2016 [12], a harmonized life cycle impact assessment method at midpoint and endpoint level. The midpoint metrics denote a potential impact located somewhere along the cause-impact pathway, while endpoint metrics reflect damage at one of three areas of protection which are human health, ecosystem quality and resource scarcity $[12,13]$. Most previous works have been characterized by a single approach, interpreting results mainly at the midpoint level, not providing a complete picture on how the impact pathway affects the environment and the three areas of protection (i.e., human health, natural environment, and resource scarcity). In line with the updated impact assessment method, a novel aspect of the ReCiPe 2016 alongside other environmental impacts is to include five novel impact pathways: water consumption on human health, terrestrial ecosystems and freshwater ecosystems; climate change on freshwater ecosystems, and tropospheric ozone formation on terrestrial ecosystems. Water consumption is one the emerging categories with the greatest interest to the life-cycle analysis (LCA) of alternative fuels [12,14]. Particularly, the consideration of water consumption and water-related effects is crucial in LCA studies that include water-intensive hydrogen production chains like electrolysis or biomass pathways.

A broad range of methods on both inventory and impact assessment level have been developed from the Water Footprint Network (WFN) and the Life Cycle Assessment (LCA) community to enable accounting and impact assessments of water use $[13,15,16]$. These methods are broadly similar and encompass both the computation of water use and its impacts, but in different phases of the assessment [17]. The water footprint assessment relies on water use indicators in the inventory phase, while LCA-based assessment focuses on impact indicators in the impact phase [13]. Still, no single method is available which comprehensively describes all potential impacts derived from freshwater use $[18,19]$. Most recently, Water Use in Life Cycle Assessment (WULCA), a working group of the UNEP-SETAC Life Cycle Initiative proposed Available WAter REmaining (AWARE) method as the 
state of the art of the current knowledge on how to assess potential impacts from water use in life cycle analysis at the midpoint level [19].

Following the evolving impact assessment methodologies within the LCA community, this research sets out a streamlined LCA analysis to enhance global knowledge at both midpoint and endpoint levels. The study identifies potential environmental impacts related to water, but also quantify the overall potential environmental impacts in order to obtain a comprehensive system-wide perspective of the environmental sustainability of each $\mathrm{H}_{2}$ production system. This LCA looks at processes with a narrower scope to find out the primary impacts, the magnitude of each type of impact and to provide default insights into the relative importance of midpoint categories and their contribution in the area of protection. A subsequent objective is to compare the life-cycle environmental profile of the studied hydrogen production methods.

\section{Materials and Methods}

\subsection{Life-Cycle Assessment (LCA) Methodology}

In the last decade, life-cycle assessment (LCA) has become the dominant tool in research, industry, and policymaking in order to study the entire life cycle of a product in terms of sustainability. Environmental LCA is defined as the compilation and evaluation of the inputs, outputs and the potential environmental impacts of a product system throughout its life cycle, i.e., from cradle-to-grave [3]. The analysis encompasses all processes relating to the functioning of a product: from the extraction of raw materials through the production, use, and maintenance of the product to the reuse and disposal of all final waste. The systematic procedure of an LCA consists of four phases: goal and scope definition, life cycle inventory analysis, impact assessment, and interpretation [3,20].

(1) Goal and scope definition: The goal definition defines the purpose of the analysis. Scope definition determines the functional unit to be analyzed and system boundaries regarding spatial and temporal characteristics and methods used for impact assessment.

(2) Life Cycle Inventory Analysis (LCI): In the LCI relevant data about energy and material inputs, emissions, wastes, and other outputs are collected and quantified.

(3) Life Cycle Impact Assessment (LCIA): The compiled system inputs and outputs are characterized and aggregated to better understand their environmental significance.

(4) Interpretation: This last LCA step summarizes the LCI and LCIA results and their quality. Conclusions and recommendations are drawn.

\subsubsection{LCA Goal and Scope Definition}

The goal of the analysis is a quick review of the major sources and quantitative midpoint and corresponding endpoint environmental impacts of each investigated hydrogen production pathways. In this LCA, a simplified approach is followed, generally by limiting data collection and using generic data where appropriate. The results should not be considered a precise prediction, but rather an indicative simulation to shed light on of pros and cons of each production pathway. Each system is modeled in a simplified "Black Box" process, summarizing the entire process chain (Figure 1). In this work, the data from some previous studies, hydrogen analysis case studies [21], and the publicly available life cycle model "Greenhouse gases, Regulated Emissions, and Energy use in Transportation" (GREET version 2017) model [22] have been used. The lifetime of each technology is considered to be 20 years. The analysis is performed from cradle-to-grave and the system boundaries include the extraction of the raw material, their production and transportation processes and the actual hydrogen production. 


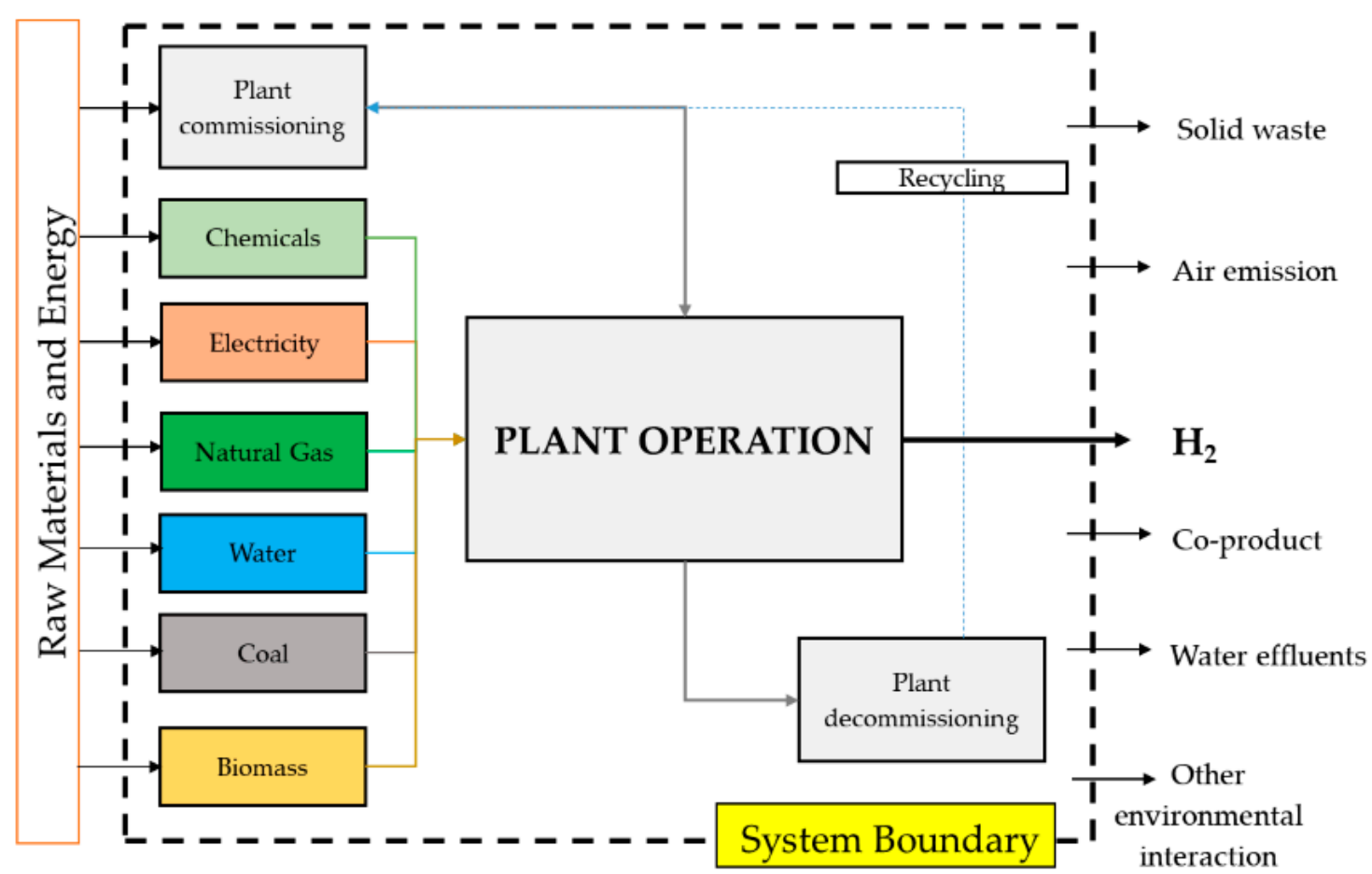

Figure 1. Generic illustration of life cycle analysis (LCA) process and graphical definition of system boundary of evaluated hydrogen pathways (modified from [23]).

The functional unit is $1 \mathrm{~kg} \mathrm{H}_{2}$ at the plant gate. All processes related to purification, upgrading, and delivery of $\mathrm{H}_{2}$ are not included in the assessment. For the evaluation of environmental impacts, all collected data refers to the production of $\mathrm{H}_{2}$. For the sake of simplicity, it is considered that the main product carries the burden of all process energy and emissions, thus, no allocation criteria and no multi-functionality were modeled within system boundaries.

\subsubsection{Hydrogen Production Technologies and Inventory}

Two primary methods are used to produce $\mathrm{H}_{2}$ : steam methane reforming (SMR) of natural gas and electrolysis of water. In the last decade, $\mathrm{H}_{2}$ production from biomass resources is gaining interest since a great quantity of biomass waste is generated by different industrial and agricultural activities offering a great potential for energy generation. Furthermore, high-temperature Electrolysis (HTE) via Solid Oxide Electrolysis Cells (SOEC) is a promising option for hydrogen production from renewable resources. The hydrogen production technologies examined in this study and their inventory are summarized below and presented in Table 1. A detailed description of each of $\mathrm{H}_{2}$ technologies is provided in the literature $[5,24,25]$. Though key input parameters have been adjusted in this study, many underlying assumptions used in the analysis rest on the default assumptions of the sub-models used for inventory data (Hydrogen Production Analysis models-H2A, and GREET model) and Ecoinvent database. The focus of this study was at the unit-operation level and for convenience, for the manufacturing infrastructure, only the main unit (i.e., electrolyzer, industrial reformer, furnace) was simulated for each unit source using generic data from Ecoinvent database. Other secondary systems were excluded because of data availability. It is recognized that such stages have negligible effects if distributed over their operational lifespan [26]. Different system configurations were modeled to check the sensitivity of the results. 
Table 1. Resources required to produce $1 \mathrm{~kg}$ of $\mathrm{H}_{2}$ from different production technologies and pathways.

\begin{tabular}{|c|c|c|c|c|c|c|c|c|c|}
\hline \multirow{2}{*}{$\begin{array}{c}\text { Type } \\
\text { Conversion pathway }\end{array}$} & \multicolumn{4}{|c|}{ Thermo-Chemical } & \multicolumn{2}{|c|}{ Electrolysis } & \multicolumn{3}{|c|}{ Biological } \\
\hline & $\begin{array}{l}\text { Steam } \\
\text { methane } \\
\text { reforming }\end{array}$ & $\begin{array}{c}\text { Coal } \\
\text { Gasification }\end{array}$ & $\begin{array}{l}\text { Biomass } \\
\text { Gasification }\end{array}$ & $\begin{array}{l}\text { Biomass } \\
\text { Reformation }\end{array}$ & $\begin{array}{l}\text { Proton } \\
\text { exchange } \\
\text { membrane } \\
(\text { PEM) }\end{array}$ & $\begin{array}{l}\text { Solid oxide } \\
\text { electrolysis } \\
\text { cells (SOEC) }\end{array}$ & $\begin{array}{l}\text { Dark fermentation + } \\
\text { microbial electrolysis } \\
\text { cell (MEC), w/out ER }\end{array}$ & $\begin{array}{c}\text { Dark fermentation + } \\
\text { microbial electrolysis } \\
\text { cell (MEC), w/ER }\end{array}$ & $\begin{array}{l}\text { Dark fermentation }+ \\
\text { microbial electrolysis cell } \\
(\mathrm{MEC}), \mathrm{w} / \mathrm{H}_{2} \text { recovery }\end{array}$ \\
\hline Abbreviation & SMR & CG & BMG & BDL-E & E-PEM & E-SOEC & DF-MEC w/out ER & DF-MEC w/ER & DF-MEC $\mathrm{w} / \mathrm{H}_{2}$ recovery \\
\hline Feedstock & Natural gas & Coal & Corn Stover & Ethanol & Electricity & Electricity & Corn Stover & Corn Stover & Corn Stover \\
\hline Natural gas $\left(\mathrm{MJ} / \mathrm{kg} \mathrm{H}_{2}\right.$ ) & 165 & - & 6.228 & - & - & 50.76 & 22.9 & - & - \\
\hline Coal $(\mathrm{kg} / \mathrm{kg} \mathrm{H})_{2}$ & - & 7.8 & - & - & - & - & - & - & - \\
\hline Biomass $\left(\mathrm{kg} / \mathrm{kg} \mathrm{H} \mathrm{H}_{2}\right)$ & - & - & 13.5 & 6.54 & - & - & 23.0 & 23.0 & 23.0 \\
\hline Electricity $(\mathrm{kWh} / \mathrm{kg} \mathrm{H})_{2}$ & 1.11 & 1.72 & 0.98 & 0.49 & 54.6 & 36.14 & 21.6 & 6.03 & 21.6 \\
\hline Water $(\mathrm{kg} / \mathrm{kg} \mathrm{H})^{1}$ & 21.869 & 2.91 & 305.5 & 30.96 & 18.04 & 9.1 & 104.225 & 104.225 & 104.225 \\
\hline Ammonia $\left(\mathrm{kg} / \mathrm{kg} \mathrm{H}_{2}\right)$ & - & - & - & - & - & - & 0.102 & 0.102 & 0.102 \\
\hline $\begin{array}{l}\text { Sodium hydroxide } \\
\left.(\mathrm{kg} / \mathrm{kg} \mathrm{H})_{2}\right)\end{array}$ & - & - & - & - & - & - & 0.389 & 0.389 & 0.389 \\
\hline Sulfuric acid $(\mathrm{kg} / \mathrm{kg} \mathrm{H})_{2}$ & - & - & - & - & - & - & 0.207 & 0.207 & 0.207 \\
\hline Glucose $\left(\mathrm{kg} / \mathrm{kg} \mathrm{H} \mathrm{H}_{2}\right)$ & - & - & - & - & - & - & 0.335 & 0.335 & 0.335 \\
\hline Corn liquor $\left(\mathrm{kg} / \mathrm{kg} \mathrm{H} \mathrm{H}_{2}\right)$ & - & - & - & - & - & - & 0.008 & 0.008 & 0.008 \\
\hline $\begin{array}{c}\text { Diammonium phosphate } \\
\left(\mathrm{kg} / \mathrm{kg} \mathrm{H}_{2}\right)\end{array}$ & - & - & - & - & - & - & 0.015 & 0.015 & 0.015 \\
\hline Reference & [27] & [28] & [29] & {$[30]$} & {$[31,32]$} & {$[25,33]$} & & [25] & \\
\hline
\end{tabular}

${ }^{1}$ For SMR, PEM, and SOEC water flow is water, deionized; For BMG and DF-MEC is water completely softened; for coal gasification and ethanol reforming is tap water. 


\section{Natural Gas Reforming}

Steam methane reforming is the most mature production and widely used process for the generation of hydrogen in large central plants. This is an important technology pathway for near-term hydrogen production and offers an efficient, economical, and environmental method with respect to commercially available production methods. The SMR process consists of the following two steps:

$$
\begin{gathered}
\text { Steam-methane reforming } \mathrm{CH}_{4}+\mathrm{H}_{2} \mathrm{O} \leftrightarrows \mathrm{CO}+3 \mathrm{H}_{2} \\
\text { Water-gas shift } \mathrm{CO}+\mathrm{H}_{2} \mathrm{O} \leftrightarrows \mathrm{CO}_{2}+\mathrm{H}_{2}
\end{gathered}
$$

SMRs use natural gas as the most common feedstock. Natural gas consists mainly of methane $\left(\mathrm{CH}_{4}\right)$, mixed with some heavier hydrocarbons and $\mathrm{CO}_{2}$. By applying high-temperature steam to the $\mathrm{CH}_{4}$, carbon monoxide, syngas mixtures (various combinations of hydrogen and carbon monoxide), steam, and electric power for customer use are created. Many life cycle assessment studies have investigated the LCA of the hydrogen via natural gas steam reforming to examine the environmental benefits and drawbacks of the competing systems $[5,8,23]$. The process flowchart and a mass balance diagram of the system under study are presented by James [27].

\section{Coal Gasification}

The gasification of coal is one fossil-based method considered attractive for $\mathrm{H}_{2}$ economy mainly due to economic reasons. Coal gasification technology produces hydrogen (Equation (3)) by reacting coal with oxygen and steam under high pressures and temperatures to create synthesis gas (carbon monoxide and hydrogen).

$$
\mathrm{CH}_{0.8}+\mathrm{O}_{2}+\mathrm{H}_{2} \mathrm{O} \leftrightarrows \mathrm{CO}+\mathrm{CO}_{2}+\mathrm{H}_{2}+\text { other species }
$$

The process flowchart and a mass balance diagram are presented by Steward [28].

Biomass Gasification

Biomass and biomass-derived fuels can be used to produce hydrogen sustainably from thermo-chemical and biological routes [34]. Biomass gasification is a promising pathway for the conversion of biomass into energy products taking place at elevated temperatures, between 500 and $1400{ }^{\circ} \mathrm{C}$ without combustion [35]. Renewable biomass is an attractive alternative and in continuous evolution because of essentially being $\mathrm{CO}_{2}$ neutral source [36]. The process flowchart and a mass balance diagram are presented by Mann and Steward [29]. Several LCA studies have already been performed in the field of hydrogen production via biomass gasification [35]. In these studies, different types of biomass feedstocks (willow, poplar, wood logging residue, corn stover, etc.) were investigated and various system configurations were examined.

\section{Ethanol Reforming}

Hydrogen production from liquid biofuels (i.e., ethanol and methanol) occurs via thermo-chemical processes [9]. Production of $\mathrm{H}_{2}$ by biomass reforming is one of the alternatives to gasification and pyrolysis of biomass for hydrogen production. Target feedstocks include ethanol, methanol and sugar alcohols (xylitol, sorbitol, glucose). The former is mainly preferred because of more advantageous thermo-dynamic properties [37]. The ethanol reforming process is a multi-step process similar to the process of SMR where ethanol is used as the sole feedstock to produce a reformate gas composed mostly of hydrogen, carbon monoxide, and some carbon dioxide.

$$
\begin{gathered}
\mathrm{C}_{2} \mathrm{H}_{5} \mathrm{OH}+\mathrm{H}_{2} \mathrm{O} \leftrightarrows 2 \mathrm{C}+4 \mathrm{H}_{2} \\
\mathrm{CO}+\mathrm{H}_{2} \mathrm{O} \leftrightarrows \mathrm{CO}_{2}+\mathrm{H}_{2}
\end{gathered}
$$


While several LCA on ethanol production systems have been carried out, only a small number of analysis have been conducted to study the steam reforming of ethanol [38]. The process flowchart and a mass balance diagram are presented by James [30].

\section{Electrolytic Production Process}

Electrolysis of water is an alternative process which can be used to produce high-quality hydrogen $(\approx 100 \%$ hydrogen) through electrochemical conversion of water to hydrogen and oxygen (Equation (6)):

$$
2 \mathrm{H}_{2} \mathrm{O}+\text { electrical energy } \rightarrow \mathrm{O}_{2}+2 \mathrm{H}_{2}
$$

The above reaction takes place in a unit called an electrolyzer, which is composed of an anode and a cathode separated by an electrolyte. Currently, main types of industrial electrolysis systems generating hydrogen are low temperature $\left(70-90{ }^{\circ} \mathrm{C}\right)$ including alkaline electrolyzers and proton exchange membrane (PEM) and high temperature $\left(650-850^{\circ} \mathrm{C}\right)$ electrolysis based on solid oxide electrolysis cells (SOEC). Electrolyzers can be integrated with solar and wind power to provide a sustainable solution for the production of hydrogen [39]. Hydrogen production from high-temperature electrolysis (HTE) using SOEC allows a greater portion of the energy required to be provided in the form of heat rather than electricity which allows obtaining higher overall system energy efficiency [33]. On the other hand, the main advantages of PEM include faster cold start, higher flexibility, and better coupling with dynamic and intermittent systems [40]. Advantages and disadvantages of electrolysis with different systems are presented by Carmo et al. [39]. Essential input for the operation is electricity and deionized water. The water used in the electrolysis process is generally pre-treated to a high level of purity [41]. For modeled electrolytic pathways, except the manufacturing, all chosen datasets about water and electricity were considered the same. A full description of high-temperature SOEC and PEM technologies is provided elsewhere [25,33,39].

\section{Dark Fermentation and Microbial Electrolysis Cell (MEC)}

Among biological methods, dark fermentation is a key technology for the production of hydrogen from a wide variety of renewable resources such as crop residues, livestock waste and food waste [42]. Dark fermentation is the fermentative conversion of organic substrate to bio-hydrogen in the absence of light [9]. This method has received considerable attention in recent years as it is comparatively cost-effective and independent of light energy [43]. It is considered the simplest process of obtaining bio-hydrogen [44]. This analysis focuses on the integrated pathway of dark fermentation with microbial electrolysis cell (MEC), as reported by Dai et al. [25].

\subsubsection{Impact Assessment}

The model ReCiPe 2016 [12] including 17 midpoint and 3 endpoint impact categories was used in this study to evaluate the environmental impacts of $\mathrm{H}_{2}$ production processes. A detailed description of the methodology is provided by Huijbregts et al. [12]. The following midpoint environmental impact categories were considered: global warming potential (GWP), stratospheric ozone depletion (ODP), ionizing radiation (IRP), photochemical oxidant formation: human health (HOFP), photochemical oxidant formation: ecosystem quality (EOFP), human toxicity potential: cancer (HTPc), human toxicity potential: non-cancer (HTPnc), terrestrial ecotoxicity potential (TETP), freshwater ecotoxicity potential (FETP), marine ecotoxicity potential (METP), freshwater eutrophication potential (FEP), fine particulate matter formation (PMFP), terrestrial acidification (TAP), Land use (LOP), water consumption potential (WCP), mineral resource scarcity (SOP), and fossil resource scarcity (FFP). Damage to human health $(\mathrm{HH})$, ecosystem quality (ED) and resource scarcity (RA) were quantified on the endpoint level. The midpoint indicators and their link with the endpoint indicators are presented in Figure 2. 


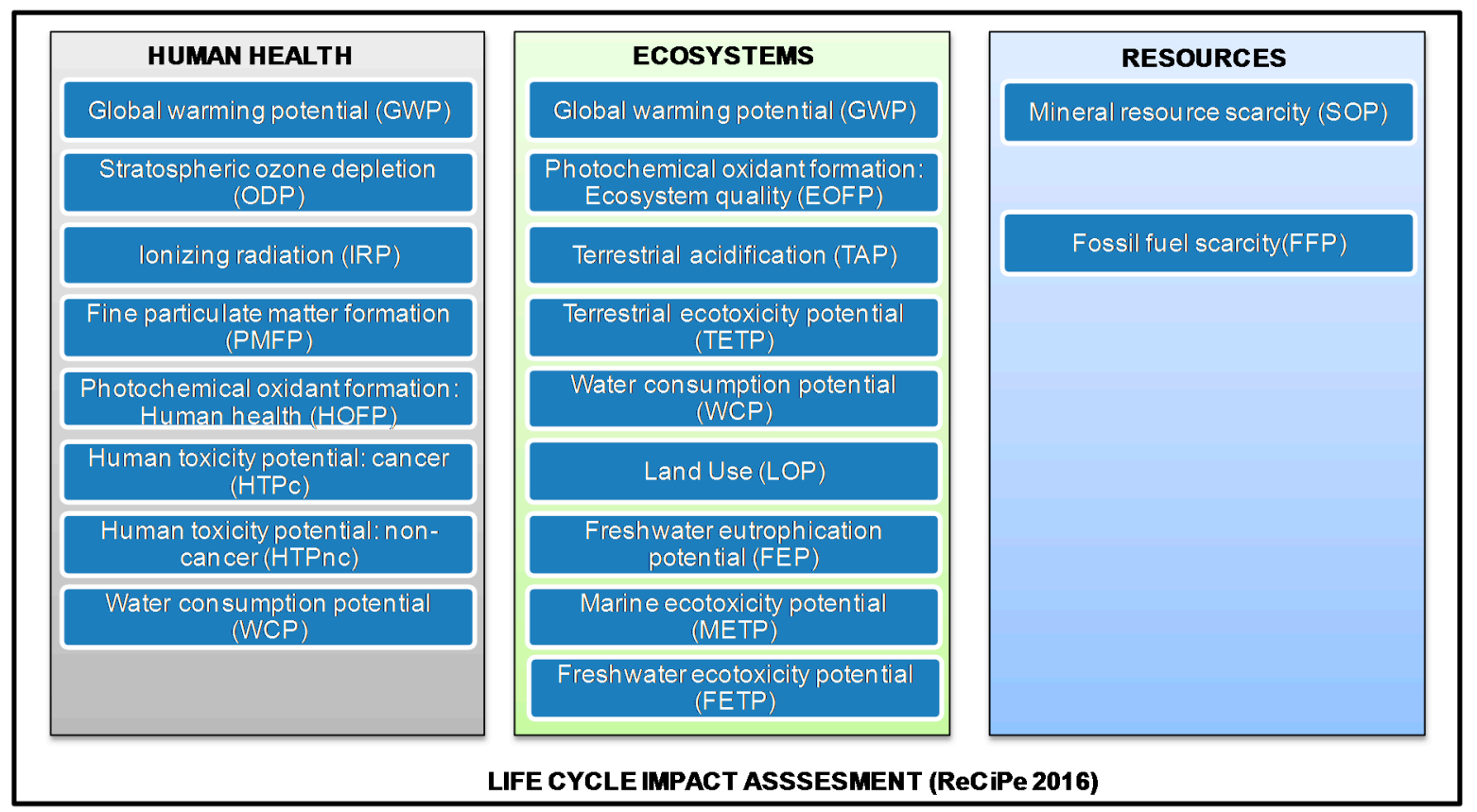

Figure 2. Midpoint impact categories and their relationship with endpoint category indicators.

The ReCiPe 2016 methodology combines three different versions of cultural theory: the egalitarian, the hierarchist and the individualist perspective. In this study, a hierarchist perspective (without any weighting) was used since it is based on the most common policy principles with regard to time-frame (100-year timeframe is the most frequently used) and referenced to in the ISO standards on LCA [45]. The default ReCiPe 2016 characterization factors used to build the environmental profile for each $\mathrm{H}_{2}$ production pathway were retrieved from [46].

Midpoint water footprint profile was further quantified using Available WAter REmaining (AWARE) method [19]. The AWARE is water scarcity footprint (WSF) method for use in LCA and for water scarcity footprint assessments. The method quantifies reduced water availability from consumption in a given watershed relative to the world average, after human and aquatic ecosystem demands have been met [19]. The WSF indicate potential environmental impacts related to each component of water used and is calculated by multiplying product of the inventory of water consumed (in $\mathrm{m}^{3}$ ) with AWARE characterization factors (AWARE100, year_average) for water scarcity footprint $[19,47]$. Water footprint impact assessment results address potential environmental impacts related to water [48].

The SimaPro software (v.8, PRé Sustainability, Amersfoort, The Netherlands) was used in this study to assist in building a representative model of the physical system and to evaluate the environmental performance of the selected technologies.

\section{Results and Discussion}

\subsection{Midpoint Environmental Performance}

Life cycle inventory flows of each production technology (Table 1) were used to calculate 18 life cycle midpoint impact category indicators (Table 2) to identify the key midpoint environmental performance indicators and subsequently identify the main processes responsible for the potential impacts of the evaluated hydrogen production processes. For water-related effect, two LCA based methods were used to analyze the environmental performance of hydrogen production methods.

The electrolytic processes (mainly proton exchange membrane fuel cell-PEM) with grid electricity has the worst performance in most of the impact categories. The highest score of impact category in 
terms of absolute values is observed for global warming potential (GWP), human non-carcinogenic toxicity (HTPnc), water consumption potential (WCP) and ionizing radiation (IRP). Generating hydrogen with a SOEC system has important potential advantages over PEM electrolysis creating less environmental impacts since $28 \%$ of energy requirement is provided in form of heat (Table 2 ). Theoretically, up to $40 \%$ of the energy required to produce $\mathrm{H}_{2}$ via SOEC electrolysis can be supplied as heat [10]. The electricity is identified as a major contributor in electrolytic production pathways (Figure 3). Irrespective of electrolyzer technology, electrolysis is an energy-intensive method of $\mathrm{H}_{2}$ production, where the environmental footprint is limited to the electricity supply chain [49]. The manufacturing phase will become the prevailing life cycle impact phase when renewable resources are used, keeping in mind that the absolute emission values go down [50]. As demonstrated in Table 2, electrolytic technologies are competitive with other technologies only if renewable electricity is used [10]. It should be noted that that the scope of ReSOC/SOEC systems is not just to produce $\mathrm{H}_{2}$, but to avoid the capping/interrupting of generated fluctuating renewable electricity, thus, reducing impacts on power system's reliability, costs and creating a competitive framework for renewable energy sources deployment. In this case, the fossil fuel-based hydrogen production methods (CG and SMR) are seen to be most environmentally harmful methods [9]. Similar observations were reported from Bhandari et al. [10] showing that GWP of electrolysis with grid electricity from the union for the coordination of transmission of electricity (UCTE) showed the worst performance, followed by conventional pathways and ranking of alternatives changed upon the change of electricity source. The environmental values might vary in literature depending on geographical location, fuel choices for electricity generation, and system boundary assumptions. Electrolysis with renewable energy sources can produce relatively low levels of global warming potential (GWP), fossil fuel scarcity (FFP), and toxicity-related impacts.

For the fossil-based system (SMR and CR) the environmental impacts are mainly determined by the raw material used in production processes (Figure 3). Although it is a slightly less efficient process, the SMR process has better slightly better performance than CG due to the lower life-cycle emissions released from processing the natural gas as opposed to coal [49]. For SMR the GWP was estimated $12.13 \mathrm{~kg} \mathrm{CO}_{2}$-eq/ $\mathrm{kg} \mathrm{H}_{2}$ being in the range from 8.9 to $12.9 \mathrm{~kg} \mathrm{CO}$-eq/ $\mathrm{kg} \mathrm{H}_{2}$ [10]. For the same process, Cetinkaya et al. [8] report a GWP value of 11.893 while Spath and Mann [5] report a value $11.8 \mathrm{~kg} \mathrm{CO}$-eq $/ \mathrm{kg} \mathrm{H}_{2}$. Even, in the fossil-based system can offer promising improvement of the environmental performance when integrated with carbon capture and storage [51]. Coupling SMR with carbon capture and storage (CCS) can produce a GWP of $3.4 \mathrm{~kg} \mathrm{CO} \mathrm{CO}_{2} \mathrm{eq} / \mathrm{kg} \mathrm{H} \mathrm{H}_{2}$ which is significantly lower than SMR stand-alone system. Verma and Kumar [51] highlighted that $\mathrm{H}_{2}$ production from integrated coal-CCS is more environmentally benign than SMR-CCS. The authors estimated that the net life cycle GHG emissions are 0.91 and $18.00 \mathrm{~kg} \mathrm{CO}_{2}$-eq $/ \mathrm{kg} \mathrm{H}_{2}$ in $\mathrm{H}_{2}$ production from coal gasification with and without CCS, respectively. The GREET model [22] reports the values of 4.08 and $21.39 \mathrm{~kg} \mathrm{CO}$-eq $/ \mathrm{kg} \mathrm{H}_{2}$ for coal gasification pathway with and without CCS, respectively. For SMR these values are 3.07 and $11.3 \mathrm{~kg} \mathrm{CO}_{2}$-eq $/ \mathrm{kg} \mathrm{H}_{2}$ with and without CCS. But while CCS offers a great advantage to reduce the GWP, it requires additional electricity and water which will lead to benefits and trade-offs for air pollution. Electricity and water usage for CCS are $0.8 \mathrm{kWh} / \mathrm{kg} \mathrm{H}_{2}$ and around $1.8 \mathrm{~kg}$ of water [24]. This underlines the adequacy of multi-criterion approaches to LCA studies to account the trade-offs between impact categories and avoid burden shifting. 
Table 2. Midpoint life-cycle environmental indicators of hydrogen production pathways (values for $1 \mathrm{~kg}$ of $\mathrm{H}_{2}$ ).

\begin{tabular}{|c|c|c|c|c|c|c|c|c|c|c|c|c|c|}
\hline \multirow[b]{2}{*}{ Impact Category ${ }^{2}$} & \multirow[b]{2}{*}{ Unit } & \multicolumn{12}{|c|}{$\mathrm{H}_{2}$ Production Pathways ${ }^{1}$} \\
\hline & & SMR & CG & BMG & BDL-E-Corn & BDL-E-Wheat & E-PEM & E-PEM-R & E-SOEC & E-SOEC-R & $\begin{array}{l}\text { DF-MEC } \\
\text { w/out ER }\end{array}$ & $\begin{array}{c}\text { DF-MEC } \\
\text { w/ER }\end{array}$ & $\begin{array}{c}\text { DF-MEC w/H } \\
\text { Recovery }\end{array}$ \\
\hline GWP & $\mathrm{kgCO}_{2}$-eq & 12.13 & 24.2 & 2.67 & 9.193 & 14.02 & 29.54 & 2.21 & 23.32 & 5.10 & 16.29 & 6.60 & 14.57 \\
\hline ODP & kg CFC-11-eq & $2.99 \times 10^{-6}$ & $3.35 \times 10^{-6}$ & $2.18 \times 10^{-5}$ & $1.70 \times 10^{-4}$ & $1.23 \times 10^{-4}$ & $1.22 \times 10^{-5}$ & $1.40 \times 10^{-6}$ & $9.36 \times 10^{-6}$ & $2.16 \times 10^{-6}$ & $4.16 \times 10^{-5}$ & $3.79 \times 10^{-5}$ & $4.11 \times 10^{-5}$ \\
\hline IRP & kBq Co-60-eq & 0.501 & 1.188 & 0.406 & 0.835 & 0.87 & 19.33 & 0.52 & 12.8505 & 0.3142 & 7.53 & 2.11 & 7.50 \\
\hline EOFP & $\mathrm{kg} \mathrm{NO}_{\mathrm{x}}$-eq & 0.0085 & 0.055 & 0.00375 & 0.037 & 0.0424 & 0.0487 & 0.0039 & 0.0349 & 0.0050 & 0.0247 & 0.01055 & 0.024 \\
\hline PMFP & $\mathrm{kg} \mathrm{PM}_{2.5}-\mathrm{eq}$ & 0.002 & 0.039 & 0.00284 & 0.007 & 0.021 & 0.0337 & 0.0041 & 0.0222 & 0.0025 & 0.0172 & 0.008266 & 0.016989 \\
\hline HOFP & $\mathrm{kg} \mathrm{NO}_{x}$-eq & 0.0089 & 0.055 & 0.00382 & 0.037 & 0.043 & 0.0492 & 0.0041 & 0.0353 & 0.0052 & 0.025 & 0.010696 & 0.023983 \\
\hline TAP & $\mathrm{kg} \mathrm{SO}_{2}$-eq & 0.0087 & 0.139 & 0.03706 & 0.124 & 0.112 & 0.1087 & 0.0118 & 0.0724 & 0.0078 & 0.104 & 0.074636 & 0.103 \\
\hline FEP & kg P-eq & 0.0007 & 0.008 & 0.00081 & 0.003 & 0.00568 & 0.0242 & 0.0014 & 0.0162 & 0.0009 & 0.0098 & 0.00312 & 0.009749 \\
\hline TETP & kg 1,4-DCB-eq & 0.0005 & 0.003 & 0.0003 & 0.007 & 0.142 & 0.012 & 0.0048 & 0.0078 & 0.0030 & 0.0041 & 0.001442 & 0.003977 \\
\hline FETP & kg 1,4-DCB-eq & 0.0208 & 0.268 & 0.01875 & 0.162 & 0.646 & 0.7519 & 0.15 & 0.4974 & 0.097 & 0.268 & 0.080308 & 0.27 \\
\hline METP & kg 1,4-DCB-eq & 0.0423 & 0.377 & 0.02706 & 0.227 & 0.483 & 1.07 & 0.22 & 0.7111 & 0.145 & 0.384 & 0.12 & 0.38 \\
\hline HTPc & $\operatorname{kg} 1,4-\mathrm{DCB}-\mathrm{eq}$ & 0.0803 & 0.64 & 0.0433 & 0.128 & 0.357 & 1.58 & 0.43 & 1.1213 & 0.356 & 0.565 & 0.16 & 0.55 \\
\hline HTPne & $\mathrm{kg} 1,4-\mathrm{DCB}-\mathrm{eq}$ & 21.36 & 277.6 & 19.69 & 284.129 & 268.94 & 764.98 & 157.25 & 507.42 & 102.26 & 272.6 & 82.10 & 269.3 \\
\hline LOP & $\mathrm{m}^{2}$ a crop-eq & 0.008272 & 0.235 & 0.02062 & 23.518 & 20.2 & 0.22 & 0.05 & 0.1525 & 0.04 & 0.104 & 0.043 & 0.102467 \\
\hline SOP & $\mathrm{kg} \mathrm{Cu}-\mathrm{eq}$ & 0.00389 & 0.004 & 0.00186 & 0.028 & 0.04 & 0.12 & 0.16 & 0.0632 & 0.09 & 0.0153 & 0.006 & 0.014159 \\
\hline FFP & kg oil-eq & 4.45 & 4.914 & 0.655 & 1.524 & 3.042 & 7.81 & 0.62 & 6.5058 & 1.72 & 4.38 & 1.68 & 3.78 \\
\hline WCP & $\mathrm{m}^{3}$ consumed & 5.77 & 13.1 & 4.94 & 2.246 & 3.875 & 223.39 & 16.40 & 146.82 & 8.82 & 84.9 & 23.98 & 84.50 \\
\hline WSF & $\mathrm{m}^{3}$ & 247.5 & 570.2 & 212.4 & 94.61 & 149.4 & 9604.3 & 629.8 & 6312.3 & 379.3 & 3650.2 & 1030.8 & 3632.9 \\
\hline
\end{tabular}

${ }^{1}$ SMR: Steam methane reforming; CG: Coal gasification; BMG: Biomass Gasification; BDL: Biomass Reformation; E-PEM: Electrolysis with Proton exchange membrane (PEM): E-PEM-R:

Electrolysis with Proton exchange membrane with wind energy; E-SOEC: Electrolysis with Solid oxide electrolysis cells (SOEC); E-SOEC-R: Electrolysis with Solid oxide electrolysis cells with wind energy; DF-MEC: Dark fermentation + microbial electrolysis cell (MEC) without energy recovery, with energy recovery and $\mathrm{H}_{2}$ recovery. ${ }^{2}$ Global warming potential (GWP); Stratospheric ozone depletion (ODP); Ionizing radiation (IRP); Photochemical oxidant formation: human health (HOFP); Photochemical oxidant formation: ecosystem quality (EOFP); Human toxicity potential: cancer $\left(\mathrm{HTP}_{c}\right)$; Human toxicity potential: non-cancer $\left(\mathrm{HTP}_{\mathrm{nc}}\right)$; Terrestrial ecotoxicity freshwater ecotoxicity (TETP); Freshwater ecotoxicity (FETP); Marine ecotoxicity (MAETP); Freshwater eutrophication potential (FEP); Fine particulate matter formation (PMFP); Terrestrial acidification (TAP); Land use (LOP); Water consumption potential (WCP); Mineral resource scarcity (SOP); Fossil resource scarcity (FFP); Water Scarcity Footprint (WSF) 

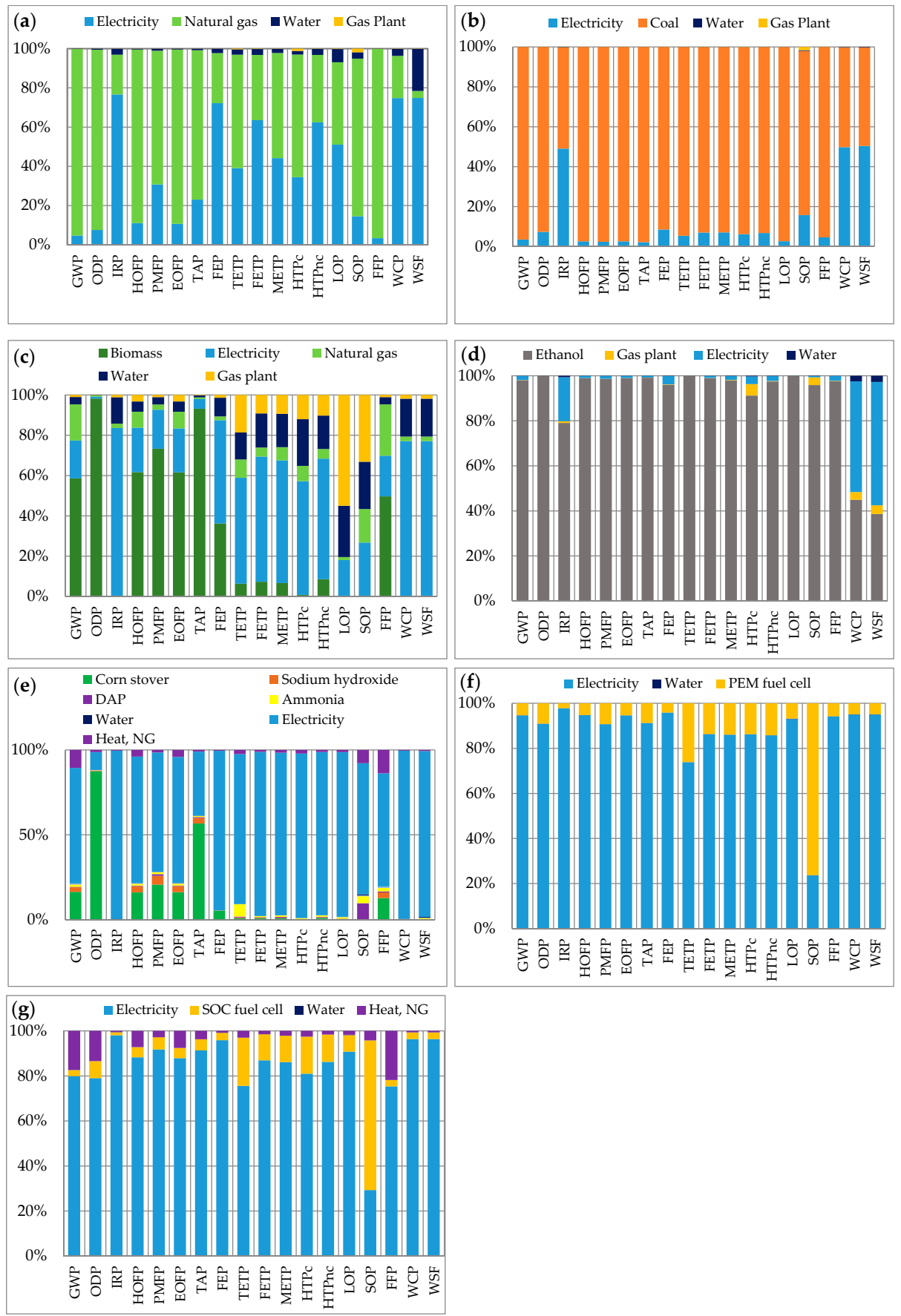

Figure 3. Aggregated contribution of processes to midpoint categories for hydrogen production technologies (Results expressed in \% of total absolute value in Table 2). (a) Steam methane reforming (b) Coal gasification; (c) Biomass Gasification; (d) Biomass Reformation; (e) Dark fermentation + microbial electrolysis cell (MEC) without energy recovery; (f) Electrolysis with Proton exchange membrane (PEM); (g) Electrolysis with Solid oxide electrolysis cells (SOEC). Abbreviations: Global warming potential (GWP); Stratospheric ozone depletion (ODP); Ionizing radiation (IRP); Photochemical oxidant formation: human health (HOFP); Photochemical oxidant formation: ecosystem quality (EOFP); Human toxicity potential: cancer $\left(\mathrm{HTP}_{\mathrm{c}}\right)$; Human toxicity potential: non-cancer $\left(\mathrm{HTP}_{\mathrm{nc}}\right)$; Terrestrial ecotoxicity freshwater ecotoxicity (TETP); Freshwater ecotoxicity (FETP); Marine ecotoxicity (MAETP); Freshwater eutrophication potential (FEP); Fine particulate matter formation (PMFP); Terrestrial acidification (TAP); Land use (LOP); Water consumption potential (WCP); Mineral resource scarcity (SOP); Fossil resource scarcity (FFP); Water Scarcity Footprint (WSF). 
From Table 2 is shown that BMG technology performs better in most of the evaluated impact categories with respect to fossil-based systems of SMR and gasification of coal. This confirms the results of other studies that biomass-derived $\mathrm{H}_{2}$ has great potential to reduce environmental footprint [52]. Hydrogen production via gasification of corn stover is characterized by a GWP potential of $2.66 \mathrm{~kg}$ $\mathrm{CO}_{2}$-eq/ $\mathrm{kg} \mathrm{H} \mathrm{H}_{2}$ which is significantly lower than fossil-based $\mathrm{H}_{2}$ production and competitive with electrolysis under renewable energy supply. For the same process, the GREET model [22] report the values of $2.68 \mathrm{~kg} \mathrm{CO}$-eq $/ \mathrm{kg} \mathrm{H}_{2}$. Susmozas et al. [52] reported a GWP of $0.405 \mathrm{~kg} \mathrm{CO}$-eq/ $\mathrm{kg} \mathrm{H_{2 }}$ while Dincer and Acar [9] around $5 \mathrm{kgCO}_{2}-\mathrm{eq} / \mathrm{kg} \mathrm{H}_{2}$. Muresan [53] compared biomass and coal gasification technologies demonstrating the superiority of biomass versus coal gasification in terms of GWP, human toxicity, and abiotic depletion potential, however, the acidification and eutrophication potentials were lower in case of the coal-to- $\mathrm{H}_{2}$ pathway. Similar observations were detected from Acar and Dincer [9] which found that the BMG gives considerably high acidification potential compared to other selected methods. Biomass feedstock and electricity are identified as the major contributor to the life cycle impact indicators of hydrogen produced from biomass gasification (Figure 3). For non-fossil $\mathrm{H}_{2}$ pathways (i.e., biomass-based systems) the impacts will depend on the type, quality, and origin of feedstock. Biomass to hydrogen is a complex process, not only because of the technical details of the conversion processes but also because of the many process types that could be employed. The yield of hydrogen from biomass varies according to the technology used, the operating parameters, and the composition of fuel used. Hydrogen production from biomass often faces technical and economic challenges especially in the small size required for the decentralized hydrogen production [54]. Moreover, biomass-based $\mathrm{H}_{2}$ production faces some major inter-connected challenges due to a more complicated supply chain water consumed is related to agricultural production processes.

Environmental analysis of ethanol reforming system with corn stover shows the significant impact in terms of stratospheric ozone depletion (ODP), terrestrial ecotoxicity (TETP), and land use (LOP). The ODP impact category influenced by $\mathrm{NO}_{x}$ and NMVOC tend to be higher in hydrogen pathways where biomass is involved. The impacts will depend on the origin of the feedstock of ethanol. The sensitivity analysis on ethanol production pathway (Table 2), shows that ethanol originating from wheat is a better choice for 13 out 17 impact categories. Ethanol from wheat distillation shows higher impacts with respect to corn stover for stratospheric ozone depletion (ODP), terrestrial acidification (TAP), human non-carcinogenic toxicity (HTPnc) and land use (LOP).

The process of hydrogen production from lignocellulosic biomass via dark fermentation combined with MEC shows a relatively good environmental performance compared to electrolysis with electricity from grid mix and coal gasification, but higher in respect to SMR and biomass gasification and ethanol reforming. Electricity requirement by the production process is identified as a major contributor to 15 impact categories hydrogen produced from dark fermentation (Figure 3). A similar conclusion was drawn from Elgoiwany et al. [55] analyzing greenhouse gas emissions in a well-to-wheel analysis. For the impact categories of stratospheric ozone depletion (ODP) and terrestrial acidification (TAP), the highest impact is attributed to biomass feedstock (i.e., corn stover). For this pathway, the yield and the energy efficiency of hydrogen production can be increased by adopting energy recovery measures where heat requirement is completely eliminated and electricity requirement is reduced from $21.6 \mathrm{kWh} / \mathrm{kg} \mathrm{H}_{2}$ to $6.03 \mathrm{~kg} \mathrm{kWh} / \mathrm{kg} \mathrm{H}_{2}$. This offers a great potential for improving environmental performance with a significant reduction of impacts (Table 2), thus being a competitive advantage with respect to other production processes. Elgoiwany et al. [55] estimated that GWP of $\mathrm{H}_{2}$ produced from the dark fermentation pathway with and without energy recovery and the values are 9.8 and $19 \mathrm{~kg}$ $\mathrm{CO}_{2}$-eq/ $\mathrm{kg} \mathrm{H}$, respectively.

At midpoint level, comparison of $\mathrm{H}_{2}$ methods using Water Scarcity Footprint (WSF) with AWARE method [19] share the same trends as the ReCiPe 2016, indicating that technologies with a high WSF can cause a high impact on the environment both from a water consumption and overall environmental impact. The water consumption and associated damage impacts are reduced in high efficient technologies which use less or do not require water. The highest contributor to the 
impacts associated with water scarcity in the majority of pathways is electricity consumption (Figure 3). Consequently, the mix of technologies deployed to produce fuels and electricity determines the associated burden on regional water resources [56]. As competition and conflicts among agriculture, industry, and cities for limited water supplies are already escalating further analysis would consider the particular water resources used and investigate the sustainability of using the water. Because water is consumed throughout the production supply chain and various production processes are heavily interdependent, assessment of water consumption throughout the life cycle of a fuel is necessary to understand water-related impacts.

\subsection{Endpoint Environmental Performance}

The LCIA-ReCiPe 2016 endpoint (damage-oriented) method is next applied to translate midpoint environmental impacts of different system configuration and technologies (Table 2) into damage impact categories of human health, ecosystem quality, and resource scarcity. Table 3 present the quantified total endpoint indicators. Calculation of performance at both midpoint and endpoint levels simplifies the interpretation of the LCIA results and complement the conclusions of a study given the trade-off between their respective robustness and environmental relevance [57]. The endpoint analysis shows similar results and trends to those observed in the ReCiPe 2016 midpoint (problem-oriented), highlighting that technologies like electrolysis, biomass gasification, and reforming of renewable bio-derived liquids may be environmentally viable approaches using optimized and renewable-based electricity supply chains.

Table 3. Endpoint scores of different $\mathrm{H}_{2}$ production processes and pathways.

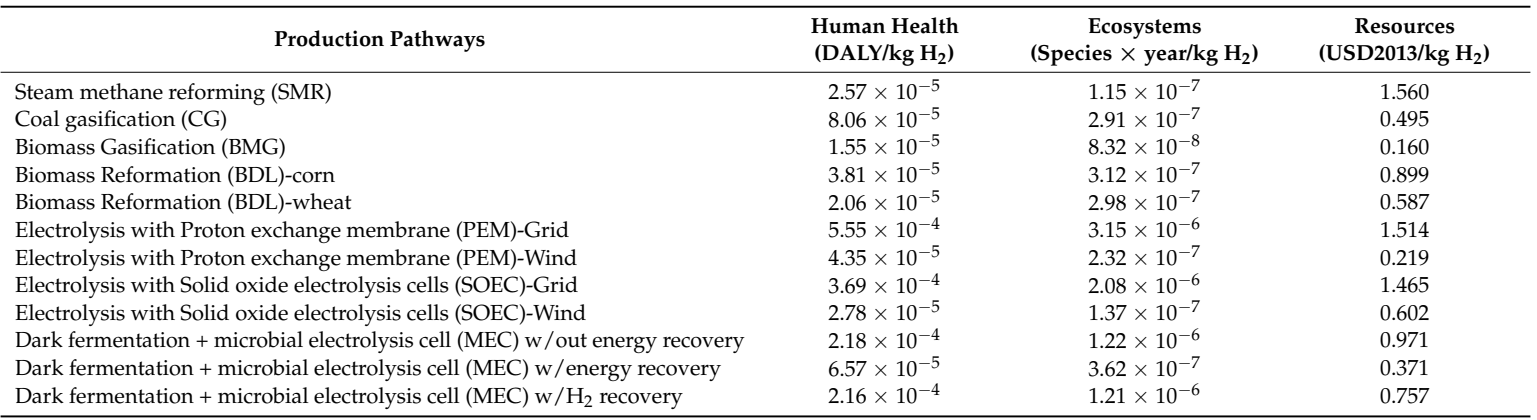

Category indicator results on the endpoint level are useful to the decision makers to interpret the midpoint indicator results and their relevance to the areas of protection (Human Health, Ecosystem Quality, and Resources impacts) which generally are the objective of the policymakers [45]. The total contribution to the different endpoint categories might be useful to guide decision makers to select relevant midpoint categories for further examination. But which midpoint environmental impact category is more important than other? Figure 4 depicts the contribution of each midpoint impact category to endpoint score. The results analysis shows that in the majority of technologies the damage on human health is mainly driven by water consumption (WCP), followed by global warming potential (GWP) and fine particulate matter formation (PMFP). Life-cycle water consumption among different pathways is dominated by electricity use. 

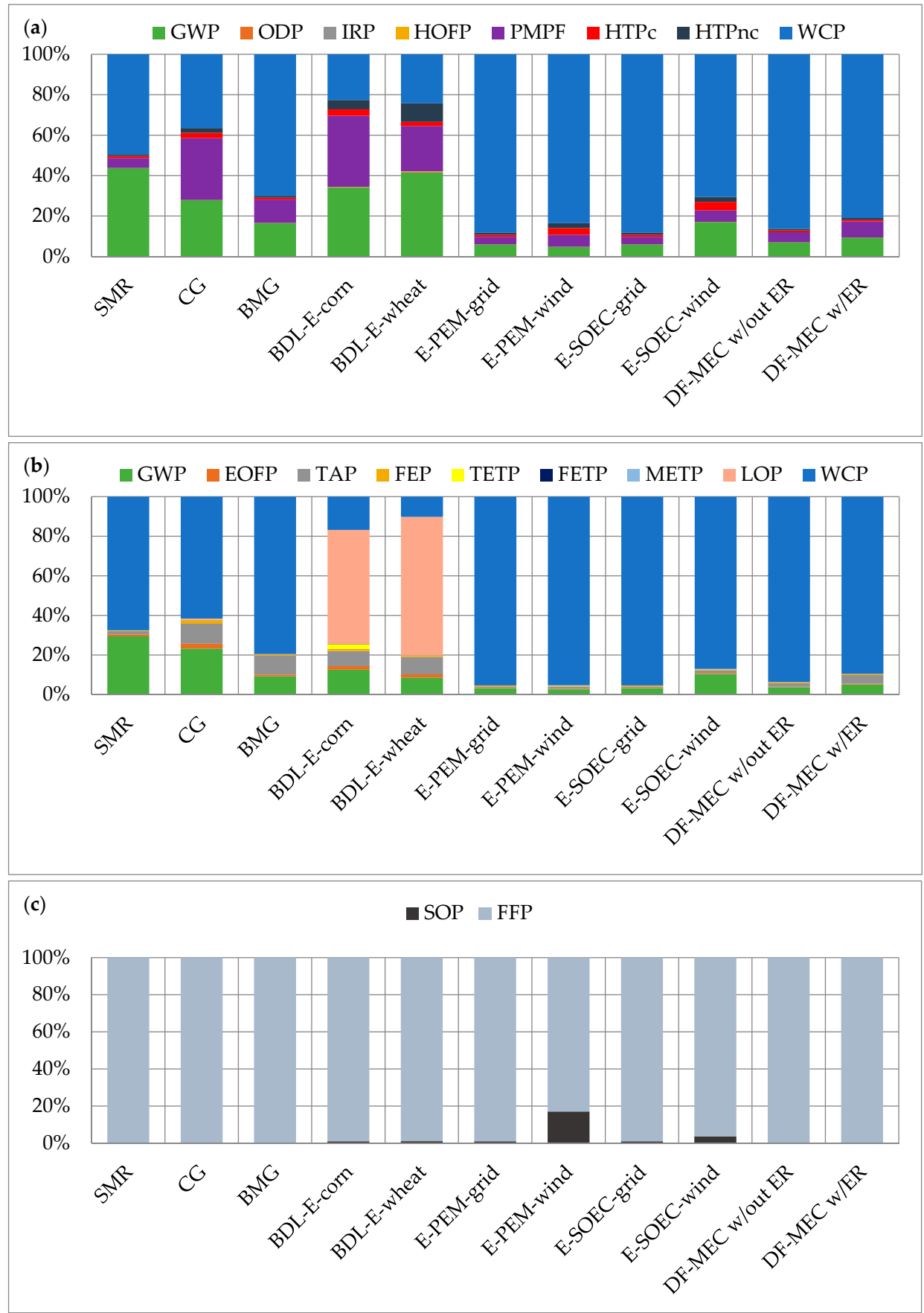

Figure 4. The contribution of midpoint to endpoint Life Cycle Impact Assessment (LCIA) results of hydrogen production pathways. (a) Human Health; (b) Ecosystems; (c) Resources; SMR: Steam methane reforming; CG: Coal gasification; BMG: Biomass Gasification; BDL: Biomass Reformation; E-PEM: Electrolysis with Proton exchange membrane (PEM); E-SOEC: Electrolysis with Solid oxide electrolysis cells (SOEC); DF-MEC: Dark fermentation + microbial electrolysis cell (MEC). Abbreviations: Global warming potential (GWP); Stratospheric ozone depletion (ODP); Ionizing radiation (IRP); Photochemical oxidant formation: human health (HOFP); Photochemical oxidant formation: ecosystem quality (EOFP); Human toxicity potential: cancer $\left(\mathrm{HTP}_{\mathrm{c}}\right)$; Human toxicity potential: non-cancer $\left(\mathrm{HTP}_{\mathrm{nc}}\right)$; Terrestrial ecotoxicity freshwater ecotoxicity (TETP); Freshwater ecotoxicity (FETP); Marine ecotoxicity (MAETP); Freshwater eutrophication potential (FEP); Fine particulate matter formation (PMFP); Terrestrial acidification (TAP); Land use (LOP); Water consumption potential (WCP); Mineral resource scarcity (SOP); Fossil resource scarcity (FFP); Water Scarcity Footprint (WSF). 
For both SMR and CG the application of CCS would reduce their GWP score, thus, the human health and ecosystem quality impact, in that case, is intimately linked with water consumption. During the operation phase, the water footprint is the highest belongs to biomass-based systems (Table 1). For conventional pathways (SMR, CG) the quantity of water consumed in production process per unit hydrogen generated does not vary substantially amongst these technologies. Nevertheless, the water consumption factors for hydrogen production via biomass gasification, SMR and electrolysis vary by feedstock source and conversion processes [58]. In the production process, both electrolysis and steam methane reforming will tend to have higher damage impacts scores for one unit of water used since they require high-quality water (low dissolved-solids concentrations) as a feedstock for the production process, which necessitates a pretreatment of water, and thereby energy and materials [24].

The analysis indicates that water-related impacts tend to be higher in production pathways where GWP and PMPF score is relatively low. This leads to an increased relevancy of the water impacts in these pathways. Extraction of $1 \mathrm{~m}^{3}$ of water has a higher impact than GWP in human health when converted from midpoint to endpoint $\left(2.22 \times 10^{-6} \mathrm{DALY} / \mathrm{m}^{3}\right.$ consumed vs. $9.28 \times 10^{-7}$ $\mathrm{DALY} / \mathrm{kg} \mathrm{CO}$-eq). The same applies also to the damage to terrestrial and aquatic ecosystems. While this assessment was done on average end-point characterization factors, with respect to life cycle perspective for each country, the outlook is even more consequential. Furthermore, the choice of cultural perspective that are using different time horizons might have a significant influence on the results [12]. Hence, proper assessment of end-point impact will require an appraisal using site-specific characterization factors.

For the damage to ecosystem quality, the impacts are mainly attributed to water consumption (WCP), followed by global warming potential (GWP) and terrestrial acidification (TAP). Only for the biomass-derived renewable liquid pathway, a large share of damage in ecosystems (ED) is attributed to the land use (LOP).

For all pathways, the environmental impacts on natural resource scarcity are largely attributed to the fossil fuel scarcity impact category.

\section{Conclusions}

This study used a streamlined environmental life cycle analysis (LCA) to evaluate the environmental profile and better understand the environmental impact of hydrogen generation processes using newly developed environmental impact indicators. An innovative aspect of this study quantification of the environmental impacts of water consumption is determined both at the midpoint (water consumption and water scarcity footprint) and at endpoint level (damage to the ecosystems and human health) alongside other environmental impacts. A well consistent framework where midpoints and endpoints increase awareness of a set of option that is available, their advantages, drawbacks, and possible challenges.

The analysis of midpoint indicators provided a technically oriented investigation which allowed identification of which step contributed more to a specific impact in the process for each production pathway and understanding of the complex dynamics. In so doing it provides a useful tool for improvement. The quantified results show there is no single "optimal" solution to all environmental problems, however, some options offer promising patterns. The numerical results show that hydrogen produced from non-fossil energy sources outperforms hydrogen produced from fossil sources (e.g., SMR and grid electrolysis) in terms of life-cycle environmental performance. Electrolysis and reforming of bio-liquids present the opportunity for environmental friendly hydrogen production using renewable resources. Electricity generation efficiency and the source will guide resource consumption, emissions, and corresponding overall life cycle impact results.

To provide a complete picture provided by the mid and endpoints, additional information of damage impact categories was used as a supplementary to the midpoint model. The endpoint modeling allowed to understand better what is underneath of human health, ecosystem quality, and resource availability. The endpoint numerical analysis in this study demonstrates that water 
consumption rate might play a fundamental role in damage impact on human health and natural environment. The results stress that it is essential to develop sustainable management practices to maximize the hydrogen output and increase the efficiency of water consumption along the fuel cycle. The study revealed the significance of water-related effects and demonstrated the need to consider a wide range of impacts (most studies have discussed only the global warming impact category) and cause-effect chains (both midpoint and endpoint modeling) when performing life cycle analysis as a means to achieve more environmentally sustainable $\mathrm{H}_{2}$ production systems. A systemic framework combining multi-method and multi-scale analysis will be helpful to get the rational result in sustainable energy decision-making for more informed decision in research, investment and policies. However, the transition to a Hydrogen economy is a complex process that cannot be fully covered by the current portfolio of LCA methods. Because of the complexity of socio-ecological systems, a future research goal is to have comprehensive dynamic multi-criteria impact analysis to support decision-making processes oriented towards sustainability. Concepts such as "Integrated Assessment" and "Sustainability Assessment" shall be used to put forward into decision-making to orient future research and investments.

Author Contributions: Andi Mehmeti and George Arampatzis conceived and designed the data collection and elaboration, modeling and data calculation in the SimaPro. Athanasios Angelis-Dimakis and Stephen J. McPhail provided direction and guidance. Sergio Ulgiati provided a critical revision of the paper. All authors analyzed the data and wrote the paper.

Conflicts of Interest: The authors declare no conflict of interest.

\section{References}

1. Marban, G.; Valdes-Soleis, T. Towards the hydrogen economy? Int. J. Hydrogen Energy 2007, 32, $1625-1637$. [CrossRef]

2. Masoni, P.; Zamagni, A. Guidance Document for Performing LCAs on Fuel Cells and $\mathrm{H}_{2}$ Technologies. FC-HyGuide: Deliverable D3.3. 2011. Available online: http:/ /www.fc-hyguide.eu/documents/10156/FC_ Guidance_Document.pdf (accessed on 30 September 2011).

3. International Organization for Standardization (ISO). ISO 14040 Environmental Management-Life Cycle Assessment-Principles and Framework; ISO: Geneva, Switzerland, 2006.

4. McManus, M.C.; Taylor, C.M. The changing nature of life cycle assessment. Biomass Bioenergy 2015, 82, 13-26. [CrossRef] [PubMed]

5. Spath, P.L.; Mann, M.K. Life Cycle Assessment of Hydrogen Production via Natural Gas Steam Reforming; National Renewable Energy Laboratory: Golden, CO, USA, 2001; NREL/TP-570-27637.

6. Utgikar, V.; Thiesen, T. Life cycle assessment of high temperature electrolysis for hydrogen production via nuclear energy. Int. J. Hydrogen Energy 2006, 31, 939-944. [CrossRef]

7. Koroneos, C.; Dompros, A.; Roumbas, G. Hydrogen production via biomass gasification-A life cycle assessment approach. Chem. Eng. Process. Process Intensif. 2008, 47, 1267-1274. [CrossRef]

8. Cetinkaya, E.; Dincer, I.; Naterer, G.F. Life cycle assessment of various hydrogen production methods. Int. J. Hydrogen Energy 2012, 37, 2071-2080. [CrossRef]

9. Acar, C.; Dincer, I. Comparative assessment of hydrogen production methods from renewable and non-renewable sources. Int. J. Hydrogen Energy 2014, 39, 1-12. [CrossRef]

10. Bhandari, R.; Trudewind, C.A.; Zapp, P. Life cycle assessment of hydrogen production via electrolysis-A review. J. Clean. Prod. 2014, 85, 151-163. [CrossRef]

11. Valente, A.; Iribarren, D.; Dufour, J. Life cycle assessment of hydrogen energy systems: A review of methodological choices. Int. J. Life Cycle Assess. 2016, 1-18. [CrossRef]

12. Huijbregts, M.A.J.; Steinmann, Z.J.N.; Elshout, P.M.F.; Stam, G.; Verones, F.; Vieira, M.; Zijp, M.; Hollander, A.; van Zelm, R. ReCiPe2016: A harmonised life cycle impact assessment method at midpoint and endpoint level. Int. J. Life Cycle Assess. 2017, 22, 138-147. [CrossRef]

13. Pfister, S.; Boulay, A.M.; Berger, M.; Hadjikakou, M.; Motoshita, M.; Hess, T.; Ridoutt, B.; Weinzettel, J.; Scherer, L.; Döll, P.; et al. Understanding the LCA and ISO water footprint: A response to Hoekstra (2016) "A critique on the water-scarcity weighted water footprint in LCA". Ecol. Indic. 2017, 72, 352-359. [CrossRef] 
14. Elgowainy, A.; Gaines, L.; Wang, M. Fuel-Cycle Analysis of Hydrogen-Powered Fuel-Cell Systems with the GREET Model; Argonne National Laboratory: Lemont, IL, USA, 2008; pp. 1252-1256.

15. Berger, M.; Finkbeiner, M. Water footprinting: How to address water use in life cycle assessment? Sustainability 2010, 2, 919-944. [CrossRef]

16. Alvarenga, R.; Lins, I.; Almeida Neto, J. Evaluation of Abiotic Resource LCIA Methods. Resources 2016, 5, 13. [CrossRef]

17. Boulay, A.-M.M.; Hoekstra, A.Y.; Vionnet, S. Complementarities of Water-Focused Life Cycle Assessment and Water Footprint Assessment. Environ. Sci. Technol. 2013, 47, 11926-11927. [CrossRef] [PubMed]

18. Kounina, A.; Margni, M.; Bayart, J.-B.; Boulay, A.-M.; Berger, M.; Bulle, C.; Frischknecht, R.; Koehler, A.; Milà i Canals, L.; Motoshita, M.; et al. Review of methods addressing freshwater use in life cycle inventory and impact assessment. Int. J. Life Cycle Assess. 2012, 18, 707-721. [CrossRef]

19. Boulay, A.M.; Bare, J.; Benini, L.; Berger, M.; Lathuillière, M.J.; Manzardo, A.; Margni, M.; Motoshita, M.; Núñez, M.; Pastor, A.V.; et al. The WULCA consensus characterization model for water scarcity footprints: Assessing impacts of water consumption based on available water remaining (AWARE). Int. J. Life Cycle Assess. 2017, 1-11. [CrossRef]

20. Angelis-Dimakis, A.; Arampatzis, G.; Assimacopoulos, D. Systemic eco-efficiency assessment of meso-level water use systems. J. Clean. Prod. 2016, 138, 195-207. [CrossRef]

21. Steward, D.; Ramsden, T.; Zuboy, J. H2A Central Hydrogen Production Model, Version 3 User Guide; National Renewable Energy Laboratory: Lakewood, CO, USA, 2012.

22. GREET Model 2017. Available online: http:/ / greet.es.anl.gov/ (accessed on 3 November 2017).

23. Dufour, J.; Serrano, D.P.; Gálvez, J.L.; Moreno, J.; González, A. Hydrogen Production from Fossil Fuels: Life Cycle Assessment of Technologies with Low Greenhouse Gas Emissions. Energy Fuels 2011, 25, 2194-2202. [CrossRef]

24. Lampert, D.; Cai, H.; Wang, Z.; Wu, M.; Han, J.; Dunn, J.; Sullivan, J.; Elgowainy, A.; Wang, M. Development of a Life Cycle Inventory of Water Consumption Associated with the Production of Transportation Fuels; Argonne National Laboratory: Lemont, IL, USA, 2015.

25. Dai, Q.; Elgowainy, A.; Kelly, J.; Han, J.; Wang, M.; Group, S.A.; Division, E.S. Life Cycle Analysis of Hydrogen Production from Non-Fossil Sources; Argonne National Laboratory: Lemont, IL, USA, 2016.

26. Bargigli, S.; Raugei, M.; Ulgiati, S. Comparison of thermodynamic and environmental indexes of natural gas, syngas, and hydrogen production processes. Energy 2004, 29, 2145-2159. [CrossRef]

27. James, B. Current (2010) Steam Methane Reformer (SMR) at Forecourt 1500 kg/day, v3.101. Available online: https:/ / www.hydrogen.energy.gov/h2a_prod_studies.html (accessed on 3 September 2017).

28. Steward, D. Current (2005) Hydrogen from Coal without $\mathrm{CO}_{2}$ Capture and Sequestration, v3.101. Available online: https: / / www.hydrogen.energy.gov/h2a_prod_studies.html (accessed on 3 September 2017).

29. Mann, M.; Steward, D.M. Current (2010) Hydrogen from Biomass via Gasification and Catalytic Steam Reforming, v3.101. Available online: http:/ / www.hydrogen.energy.gov/h2a_production.html (accessed on 3 September 2017).

30. James, B. Current (2010) Ethanol Steam Reformer (SR) at Forecourt $1500 \mathrm{~kg} /$ day, Version 3.0. Strategic Analysis, Inc.: Arlington, VA, USA. Available online: https:/ /www.hydrogen.energy.gov/h2a_prod_studies. html (accessed on 3 September 2017).

31. Saur, G.; Ramsden, T.; James, B.; Collella, W. Current (2010) Hydrogen Production from Distributed Grid PEM Electrolysis, v3.101. Available online: https://www.hydrogen.energy.gov/h2a_prod_studies.html (accessed on 3 September 2017).

32. James, B.D.; Moton, J.M. Techno-Economic Analysis of PEM Electrolysis for Hydrogen Production; Electrolytic Hydrogen Production Workshop, National Renewable Energy Laboratory: Golden, CO, USA, 2014.

33. Harvego, E.A.; O'Brien, J.E.; McKellar, M.G. System evaluation and life-cycle cost analysis of a commercial scale high-temperature electrolysis hydrogen production plant. In Proceedings of the ASME 2012 International Mechanical Engineering Congress and Exposition, Houston, TX, USA, 9-15 November 2012; Volume 6, pp. 875-884. [CrossRef]

34. Kirtay, E. Recent advances in production of hydrogen from biomass. Energy Convers. Manag. 2011, 52, 1778-1789. [CrossRef]

35. Iribarren, D.; Susmozas, A.; Petrakopoulou, F.; Dufour, J. Environmental and exergetic evaluation of hydrogen production via lignocellulosic biomass gasification. J. Clean. Prod. 2014, 69, 165-175. [CrossRef] 
36. Albertazzi, S.; Basile, F.; Brandin, J.; Einvall, J.; Hulteberg, C.; Fornasari, G.; Rosetti, V.; Sanati, M.; Trifirò, F.; Vaccari, A. The technical feasibility of biomass gasification for hydrogen production. Catal. Today 2005, 106, 297-300. [CrossRef]

37. King, D.L.; Contact, P.; Wang, Y.; Cao, J.; Xia, G.; Roh, H.; Platon, A. IV. A. 6 Production of Hydrogen by Biomass Reforming; Pacific Northwest National Laboratory: Richland, WA, USA, 2005; pp. 98-105.

38. Dufour, J.; Serrano, D.P.; Moreno, J.; Gálvez, J.L.; Dufour, J.; Technology, E.; Rey, U.; Carlos, J.; Carlos, R.J.; Energía, I. Life Cycle Assessment of Hydrogen Production Processes: Steam Reforming of Natural Gas, Ethanol and Bioethanol; Zentralbibliothek: Jülich, Germany, 2010; Volume 78.

39. Carmo, M.; Fritz, D.L.; Mergel, J.; Stolten, D. A comprehensive review on PEM water electrolysis. Int. J. Hydrogen Energy 2013, 38, 4901-4934. [CrossRef]

40. Götz, M.; Lefebvre, J.; Mörs, F.; McDaniel Koch, A.; Graf, F.; Bajohr, S.; Reimert, R.; Kolb, T. Renewable Power-to-Gas: A technological and economic review. Renew. Energy 2016, 85, 1371-1390. [CrossRef]

41. Lampert, D.J.; Cai, H.; Elgowainy, A. Wells to wheels: Water consumption for transportation fuels in the United States. Energy Environ. Sci. 2016, 9, 787-802. [CrossRef]

42. Guo, X.M.; Trably, E.; Latrille, E.; Carrre, H.; Steyer, J.P. Hydrogen production from agricultural waste by dark fermentation: A review. Int. J. Hydrogen Energy 2010, 35, 10660-10673. [CrossRef]

43. Jaseena, K.A.; Sosamony, K.J. Practical Aspects of Hydrogen Production by Dark Fermentation-A Review. IRACST Eng. Sci. Technol. Int. J. 2016, 6, 2250-3498.

44. Cardoso, V.; Romão, B.B.; Silva, F.T.M.; Santos, J.G.; Batista, F.R.X.; Ferreira, J.S. Hydrogen Production by Dark Fermentation. Chem. Eng. Trans. 2014, 38, 481-486. [CrossRef]

45. Goedkoop, M.; Heijungs, R.; De Schryver, A.; Struijs, J.; van Zelm, R. ReCiPe 2008. A Life Cycle Impact Assessment Method Which Comprises Harmonised Category Indicators at the Midpoint and the Endpoint Level. Report I: Characterisation. 2013. Available online: http:/ /www.rivm.nl/en/Topics/L/Life_Cycle_ Assessment_LCA/Downloads (accessed on 20 September 2017).

46. Huijbregts, M.A.J.; Steinmann, Z.J.; Elshout, P.M.F.; Stam, G.; Verones, F.; Vieira, M.D.M.; Zijp, M.; van Zelm, R. ReCiPe 2016: A Harmonized Life Cycle Impact Assessment Method at Midpoint and Enpoint Level-Report 1: Characterization; National Institute for Public Health and the Environment: Bilthoven, The Netherlands, 2016.

47. Boulay, A.-M.M.; Lathuillière, M.J. Water Use in LCA-Methodology. In Encyclopedia of Sustainable Technologies; Abraham, M., Ed.; Elsevier: Amsterdam, The Netherlands, 2017; pp. 293-301.

48. International Organization for Standardization (ISO). Environmental Management_Water Footprint_Principles, Requirements and Guidelines; ISO: Geneva, Switzerland, 2014.

49. Simons, A.; Bauer, C. Life Cycle Assessment of Hydrogen Production. In Transition to Hydrogen: Pathways toward Clean Transportation; Wokaun, A., Wilhelm, E., Eds.; Cambridge University Press: Cambridge, UK, 2011; pp. 13-57.

50. Fischer, M.; Fltenbacher, M.; Schuller, O. Life Cycle Impact Assessment; Ecological City Transport System-ECTOS Report 16; Institut für Kunststoffprüfung und Kunststoffkunde: Stuttgart, Germany, 2005.

51. Verma, A.; Kumar, A. Life cycle assessment of hydrogen production from underground coal gasification. Appl. Energy 2015, 147, 556-568. [CrossRef]

52. Susmozas, A.; Iribarren, D.; Dufour, J. Life-cycle performance of indirect biomass gasification as a green alternative to steam methane reforming for hydrogen production. Int. J. Hydrogen Energy 2013, 38, 9961-9972. [CrossRef]

53. Muresan, M.; Cormos, C.C.; Agachi, P.S. Comparative life cycle analysis for gasification-based hydrogen production systems. J. Renew. Sustain. Energy 2014, 6, 013131. [CrossRef]

54. Sara, H.R.; Enrico, B.; Mauro, V.; Andrea, D.C.; Vincenzo, N. Techno-economic Analysis of Hydrogen Production Using Biomass Gasification-A Small Scale Power Plant Study. Energy Procedia 2016, 101, 806-813. [CrossRef]

55. Pi, A.E.; Dai, Q.; Han, J.; Wang, M. Life Cycle Analysis of Emerging Hydrogen Production Technologies; Argonne National Laboratory: Lemont, IL, USA, 2016; pp. 1-5.

56. Spang, E.S.; Moomaw, W.R.; Gallagher, K.S.; Kirshen, P.H.; Marks, D.H. The water consumption of energy production: An international comparison. Environ. Res. Lett. 2014, 9. [CrossRef] 
57. Curran, M.A. Overview of Goal and Scope Definition in Life Cycle Assessment. In Goal and Scope Definition in Life Cycle Assessment; Springer: Dordrecht, The Netherlands, 2017; pp. 1-62, ISBN 940240855X.

58. Elgowainy, A.; Han, J.; Lee, U.; Li, J.; Dunn, J.; Wang, M. IX. 2 Life-Cycle Analysis of Water Consumption for Hydrogen Production Contribution to Achievement of DOE; Argonne National Laboratory: Lemont, IL, USA, 2016; pp. 1-4. 